\title{
Pengaruh Media Pembelajaran Geogebra Pada Materi Fungsi Kuadrat Terhadap Motivasi dan Hasil Belajar Peserta Didik
}

\author{
${ }^{1}$ Nur Hamidah, ${ }^{2}$ Iis Nur Afidah, ${ }^{3}$ Lutfi Wahyu Setyowati, ${ }^{4}$ Sutini, 5 Junaedi \\ 1,2,3,4,5Program Studi Pendidikan Matematika, Fakultas Tarbiyah dan Keguruan, \\ UIN Sunan Ampel Surabaya \\ 1Email: nurhamidah493@gmail.com
}

\begin{abstract}
This study aims to determine the effect of Geogebra learning media on the quadratic function material on motivation and learning outcomes in class IX MTsN Gresik. The method of this research used experimental research mapped in class IX $-C$ and IX-D. Class IX-C as a control class and class IX-D as an experimental class. Where each class there are 28 students. Data collection techniques used were pretest, post-test and questionnaire. Pretest and post-test were used to determine effect of Geogebra on student learning outcomes, while the questionnaire was used to determine the effect of Geogebra on students' learning motivation. Data analysis uses z-test analysis. The results of the study showed that : (1) Geogebra learning media on quadratic function material influences students' learning motivation, (2) student learning outcomes using Geogebra learning media on quadratic function material are better than students who do not use Geogebra.
\end{abstract}

Keyword: Geogebra, motivation and learning outcomes, quadratic function.

\begin{abstract}
Abstrak: Penelitian ini bertujuan untuk mengetahui pengaruh media pembelajaran Geogebra pada materi fungsi kuadrat terhadap motivasi dan hasil belajar di kelas IX MTs Negeri Gresik. Metode penelitian yang digunakan adalah penelitian eksperimen yang dipetakan pada kelas IX-C dan IXD. Kelas IX-C sebagai kelas kontrol dan kelas IX-D sebagai kelas eksperimen. Dimana masingmasing kelas tersebut terdapat 28 peserta didik. Teknik pengumpulan data yang digunakan adalah pretest, postest dan angket. Pretest dan postest digunakan untuk mengetahui pengaruh Geogebra terhadap hasil belajar peserta didik, sedangkan angket digunakan untuk mengetahui pengaruh Geogebra terhadap motivasi belajar peserta didik. Analisis data menggunakn analisis uji-z. Hasil penelitian yang dilakukkan menunjukkan bahwa: (1) media pembelajaran Geogebra pada materi fungsi kuadrat berpengaruh terhadap motivasi belajar peserta didik (2) hasil belajar peserta didik menggunakan media pembelajaran Geogebra pada materi fungsi kuadrat lebih baik daripada peserta didik yang tidak menggunakan Geogebra.
\end{abstract}

Kata Kunci: Geogebra, motivasi dan hasil belajar, fungsi kuadrat.

\section{PENDAHULUAN}

Pendidikan adalah usaha sadar dan terencana untuk mewujudkan suasana belajar dan proses pembelajaran agar peserta didik secara aktif mengembangkan potensi dirinya untuk memiliki kekuatan spiritual keagamaan, pengendalian diri, kepribadian, kecerdasan, akhlak mulia, serta keterampilan yang diperlukan dirinya, masyarakat, bangsa dan negara (UU Nomor 20 Tahun 2003, pasal 1 ayat 1). Suasana belajar dan proses pembelajaran merupakan kata kunci yang menyertai usaha sadar dan terencana pada 
definisi pendidikan tersebut yang harus dikelola sedemikian rupa sehingga dapat menghasilkan kualitas pendidikan yang berkualitas baik pada tataran lokal, regional, dan internasional.

Tinggi rendahnya grade kualitas pendidikan merupakan gambaran dari kualitas pembelajaran yang dipraktekkan para guru dalam proses pembelajaran di dalam kelas. Manakala pembelajaran dianggap sebagai suatu sistem, maka guru merupakan salah satu komponen yang paling berpengaruh terhadap keberhasilan sistem tersebut (Sanjaya, 2009:3). Urgennya peran guru dalam pembelajaran menjadi justifikasi tingginya ekspektasi terhadap guru yang kompeten (high competence) dalam memandu pembelajaran yang akan melakukan transformasi pengetahuan (knowledge), sikap (attitude), dan keterampilan (skill) terhadap peserta didik.

Seperti diketahui, motivasi belajar pada peserta didik tidak sama kuatnya, ada peserta didik yang motivasinya bersifat intrinsik dimana kemauan belajarnya lebih kuat dan tidak tergantung pada faktor di luar dirinya. Sebaliknya dengan peserta didik yang motivasi belajarnya bersifat ekstrinsik, kemauan untuk belajar sangat tergantung pada kondisi di luar dirinya. Namun demikian, di dalam kenyataan motivasi ekstrinsik inilah yang banyak terjadi, terutama pada anak-anak dan remaja dalam proses belajar. Proses pembelajaran akan berhasil manakala peserta didik mempunyai motivasi dalam belajar. Oleh karena itu, guru perlu menumbuhkan motivasi belajar peserta didik. Untuk memperoleh hasil belajar yang optimal, guru dituntut kreatif membangkitkan motivasi belajar peserta didik. Sebelum masuk kepada bagimana upaya seorang guru dalam memotivasi belajar peserta didik penulis terlebih dahulu akan membahas tentang apa itu motivasi, yang akan dilanjutkan dengan hal-hal yang perlu dilakukan oleh guru dalam memotivasi belajar peserta didik, ciri-ciri peserta didik termotivasi dan fungsi motivasi bagi peserta didik.

Perkembangan ilmu pengetahuan dan teknologi pada dasarnya akan bermanfaat untuk lebih mempermudah manusia dalam menjalankan segala aktivitas di berbagai bidang kehidupan. Salah satu contohnya pada bidang pendidikan termasuk pendidikan matematika. Matematika merupakan mata pelajaran yang bidang kajiannya abstrak dan memerlukan daya berpikir logis sehingga untuk menyampaikannya diperlukan suatu media agar peserta didik menjadi lebih memahami materi yang disampaikan dan merangsang peserta didik untuk meningkatkan kemampuan daya berpikir logis. Beberapa media yang paling akrab dan hampir semua sekolah termasuk perguruan tinggi memanfaatkan adalah media cetak (buku) dan papan tulis. Selain itu, banyak juga sekolah yang telah memanfaatkan jenis media lain seperti gambar, model, dan Overhead Projector (OHP), dan obyek-obyek nyata. Sedangkan media lain seperti kaset audio, video, VCD, slide (film bingkai), program pembelajaran komputer masih jarang digunakan meskipun sebenarnya tidak asing lagi bagi sebagian besar guru. Meskipun demikian, sebagai seorang guru alangkah baiknya mengenal beberapa jenis media pembelajaran tersebut. Hal ini dimaksudkan agar mendorong kita untuk mengadakan dan memanfaatkan media tersebut dalam kegiatan pembelajaran di kelas (Depdiknas, 2003).

Media pembelajaran merupakan suatu sarana/alat bantu guru untuk menyampaikan pesan ataupun informasi agar dapat diterima dengan baik dan menarik oleh peserta didik. Pemilihan media pembelajaran yang tepat akan berpengaruh dalam mewujudkan tercapainya tujuan pembelajaran secara lebih optimal.

Pemanfaatan teknologi informasi (TI) dalam pembelajaran membawa perubahan tradisi atau budaya pembelajaran. Pemanfaatan TI dalam pembelajaran dapat menjadi sistem pembelajaran mandiri (instructor independent) atau juga digabungkan dengan proses pembelajaran langsung (tatap muka di kelas) yang mengandalkan kehadiran guru. Dalam pembelajaran matematika, pemanfaatan teknologi dapat membantu meningkatkan 
kualitas pembelajaran. GeoGebra sebagai salah satu perangkat lunak matematika dapat dimanfaatkan untuk membantu guru dalam membuat lembar kerja interaktif yang akan mempermudah peserta didik memahami beberapa konsep, relasi, dan prinsip tertentu di matematika. GeoGebra dapat digunakan dalam pembelajaran matematika untuk demonstrasi, abstraksi, dan visualisasi. Selain itu juga dapat berfungsi sebagai alat bantu konstruksi, eksplorasi, dan penemuan matematika, sebagai perangkat lunak pembangun bahan ajar (authoring tools), dan sebagai alat untuk mengecek jawaban soal. Beberapa manfaat program Geogebra dalam pembelajaran matematika sebagai berikut: a) Dapat menghasilkan lukisan-lukisan geometri dengan cepat dan teliti, bahkan yang rumit. b) Adanya fasilitas animasi dan gerakan-gerakan manipulasi yang dapat memberikan pengalaman visual dalam memahami konsep geometri. c) Dapat dimanfaatkan sebagai bahan balikan/evaluasi untuk memastikan bahwa lukisan geometri yang telah dibuat memang benar. d) Mempermudah untuk menyelidiki atau menunjukkan sifat-sifat yang berlaku pada suatu objek geometri. Dengan demikian, penggunaan GeoGebra dalam pembelajaran matematika akan sangat membantu pembelajaran di kelas.

Ada beberapa sekolah/madrasah di Gresik salah satunya yakni MTs Negeri Gresik, yang mengeluhkan bahwa untuk bab materi fungsi kuadrat ada kesulitan untuk memahamkan kepada peserta didik. Tingkat penyerapan peserta didik terhadap materi fungsi kuadrat masih sangat rendah. Jika hanya menggunakan metode konvensional yaitu metode mengajar yang hanya guru menerangkan dengan metode ceramah secara klasikal, guru hanya menggunakan papan tulis saja tanpa menggunakan media pembelajaran lain peserta didik juga terlihat kurang antusias dan kurang aktif dalam pembelajaran.

Berdasarkan latar belakang masalah di atas maka dapat diidentifikasi permasalahan yang muncul yaitu peserta didik kelas IX-C dan IX-D kesulitan dalam mempelajari fungsi kuadrat sehingga pemahaman yang diperoleh kurang maksimal. Dengan demikian, rumusan masalah dalam penelitian ini adalah: (1) apakah media pembelajaran GeoGebra berpengaruh terhadap motivasi belajar peserta didik dalam materi fungsi kuadrat? (2) apakah media pembelajaran GeoGebra berpengaruh terhadap hasil belajar peserta didik dalam materi fungsi kuadrat? Tujuan penelitian ini adalah untuk mendeskripsikan pengaruh aplikasi GeoGebra terhadap motivasi dan hasil belajar peserta didik dalam materi fungsi kuadrat. Adapun manfaat yang diharapkan dari hasil penelitian ini adalah dengan pemanfaatan GeoGebra dalam pembelajaran diharapkan dapat membantu: 1) peserta didik, dalam bereksplorasi lebih mendalam dan meningkatkan pemahaman terhadap materi fungsi kuadrat ditinjau dari bentuk aljabarnya; 2) guru, dalam menjelaskan materi fungsi kuadrat ditinjau dari bentuk aljabarnya, dan dalam menumbuhkan minat dan motivasi belajar peserta didik dalam belajar matematika.

Geogebra Sebagai Media Pembelajaran Matematika

Pesatnya perkembangan teknologi komputer saat ini, manfaat komputer telah dirasakan di berbagai sektor kehidupan. Dalam sektor pendidikan misalnya, pemanfaatan komputer sudah berkembang tidak hanya sebagai alat yang hanya dipergunakan untuk urusan keadministrasian saja, melainkan juga dimungkinkan untuk digunakan sebagai salah satu alternatif dalam pemilihan media pembelajaran. Adanya komputer multimedia yang mampu menampilkan gambar maupun teks yang diam dan bergerak (animasi) serta bersuara sudah saatnya untuk dapat dijadikan sebagai salah satu alternatif pilihan media pembelajaran yang efektif. Hal semacam ini perlu ditanggapi secara positif oleh para guru sehingga komputer dapat menjadi salah satu media yang dapat membantu dalam mengoptimalkan pembelajaran di sekolah maupun di perguruan tinggi (Sumber: P4TK Matematika, 2009: 1). 
Menurut Simon (Wena, 2009 : 203) terdapat tiga model penyampaian materi dalam metode pembelajaran berbasis komputer, yaitu sebagai berikut:

a. Latihan dan praktik. Dalam model pembelajaran berbasis komputer ini peserta didik diberikan pertanyaan-pertanyaan atau masalah untuk dipecahkan, kemudian komputer akan memberi respon (umpan balik) atas jawaban yang diberikan peserta didik. Metode ini hampir sama dengan pekerjaan rumah yang diberikan pada peserta didik, kemudian guru memberikan umpan balik. Namun, dalam pembelajaran berbasis komputer, balikan akan diberikan segera pada masing-masing peserta didik sehingga tahu dimana letak kesalahannya.

b. Tutorial. Model pembelajaran berbasis komputer ini menyediakan rancangan pembelajaran yang kompleks yang berisi materi pembelajaran, latihan yang disertai umpan balik.

c. Simulasi. Model pembelajaran berbasis komputer ini menyajikan pembelajaran dengan sistem simulasi yang berhubungan dengan materi yang dibahas. Berbagai manfaat program komputer dalam pembelajaran matematika dikemukakan oleh Kusumah (2003). Menurutnya, program-program komputer sangat ideal untuk dimanfaatkan dalam pembelajaran konsep-konsep matematika yang menuntut ketelitian tinggi, konsep atau prinsip yang repetitif, penyelesaian grafik secara tepat, cepat, dan akurat. Berbagai program komputer telah dikembangkan dan dapat digunakan dalam pembelajaran matematika, salah satunya adalah GeoGebra. GeoGebra merupakan kependekan dari geometry (geometri) dan algebra (aljabar), tetapi program ini tidak hanya mendukung untuk kedua topik tersebut, tapi juga mendukung banyak topik matematika di luar keduanya. Menurut Hohenwarter dan Fuchs (Suprihady: 2015:1), GeoGebra adalah software serbaguna untuk pembelajaran matematika di sekolah dan perguruan tinggi. Dalam pembelajaran matematika GeoGebra dapat dimanfaatkan sebagai berikut;

1) GeoGebra untuk media demontrasi dan visualisasi.

2) GeoGebra sebagai alat bantu kontruksi.

3) GeoGebra sebagai alat bantu penemuan konsep matematika.

4) GeoGebra untuk menyiapkan bahan-bahan pengajaran.

Materi-materi yang memuat konsep geometri, aljabar dan kalkulus dapat mengunakan GeoGebra sebagai media pembelajarannya. Namun, semua itu tergantung dari bagaimana kreativitas dan kemampuan guru mengolah materi menjadi lebih menarik menggunakan GeoGebra, dan tentunya dengan model, metode dan strategi pembelajaran yang juga cocok. Hal ini, GeoGebra digunakan dalam pembelajaran matematika pada fungsi linier, fungsi kuadrat, fungsi polinom dan fungsi logaritma.

Menurut Mahmudi, A (2010: 471) mengatakan bahwa pemanfaatan program GeoGebra memberikan beberapa keuntungan, di antaranya adalah sebagai berikut:

1) Lukisan-lukisan yang biasanya dihasilkan dengan cepat dan teliti dibandingkan dengan menggunakan pensil, penggaris, atau jangka.

2) Adanya fasilitas animasi dan gerakan-gerakan manipulasi (dragging) pada program GeoGebra dapat memberikan pengalaman visual yang lebih jelas kepada siswa dalam memahami konsep matematika.

3) Dapat dimanfaatkan sebagai balikan/evaluasi untuk memastikan bahwa lukisan yang telah dibuat benar.

4) Mempermudah guru/siswa untuk menyelidiki atau menunjukkan sifat-sifat yang berlaku pada suatu objek matematika. Hal ini GeoGebra digunakan sebagai alat bantu bagi siswa untuk menemukan suatu konsep matematis, misalnya tempat kedudukan titik-titik atau karakteristik grafik parabola. 


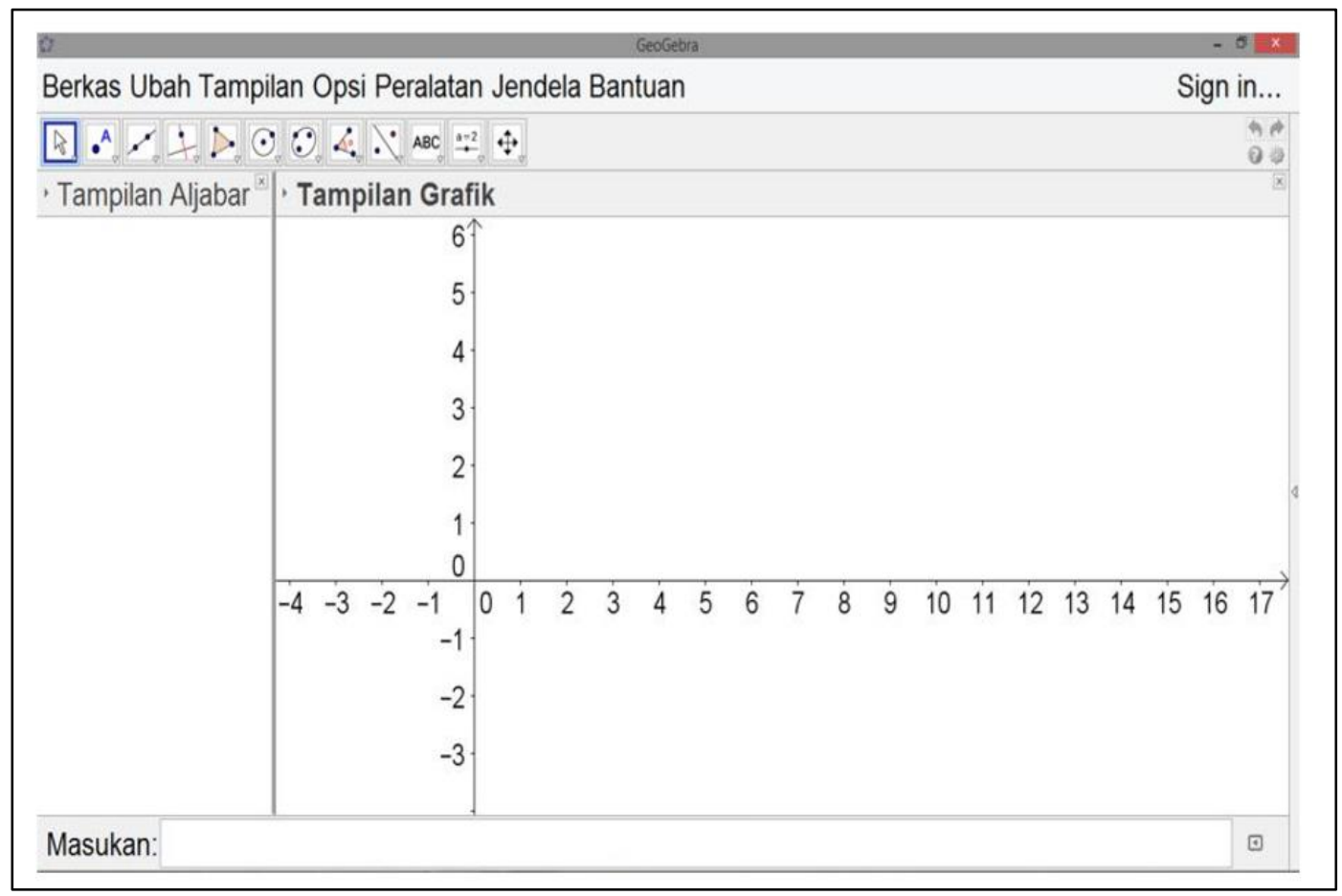

Gambar 1. Tampilan Awal GeoGebra

Tampilan depan dari geogebra sangat sederhana terdiri dari: 1) Menu: terdiri dari berkas, ubah, tampilan, opsi, peralatan, jendela, dan bantuan; 2) Tool Bar: berisi icon-icon atau symbol-simbol; 3) Jendela Kiri: di jendela ini tempat ditampilkannya bentuk aljabar; 4) Jendela Kanan: yaitu tempat ditampilkannya grafik; 5) Masukan: yang terletak di kiri bawah; 6) Simbol: berisi daftar simbol. Opersai dasar yang biasa digunakan dalam matematika khususnya pada materi fungsi kuadrat adalah penjumlahan, penngurangan, perkalian, pembagian dan pemangkatan. Berikut ini daftar operasi dasar dan tombol pada keybord yang harus ditekan antara lain (penjumlahan + , pengurangan -, perkalian * atau tombol spasi, pembagian /, dan pemangkatan $\left.{ }^{\wedge}\right)$.

\section{METODE}

Pada penelian ini menggunakan teknik analisis statistik uji-z yang dilakukan dengan dua kali tes. Pertama yaitu pre test yang dilakukan tanpa media pembelajaran geogebra. Tes yang kedua yaitu post test yang dilakukan setelah media pembelajaran geogebra diterapkan di kelas, dengan tujuan untuk mengetahui hasil belajar peserta didik. Sedangkan untuk mengetahui motivasi belajar peserta didik menggunakan angket dan wawancara.

Penelitian ini dilaksanakan di MTsN Gresik, sebanyak 2 kali pertemuan pada tanggal 9 September 2019 dan 10 September 2019. Sampel yang diambil terdiri dari dua kelas yaitu kelas IX D dan IX C. Kelas IX C sebagai kelas eksperimen yakni kelas yang mendapat perlakuan dan kelas IX D sebagai kelas kontrol yakni kelas yang tidak mendapat perlakuan. Pada penelitian ini kelas eksperimen akan menggunakan media geogebra dan pada kelas kontrol menggunakan rumus.

\section{HASIL DAN PEMBAHASAN}

Data hasil penelitian ini berupa nilai pretes, postes dan data angket mengenai motovasi belajar siswa. Data akan dianalisis untuk mengetahui perbedaan motivasi dan hasil belajar siswa sebelum dan sesudah penerapan media pembelajaran Geogebra. 
1. Hasil Pretest

Sebelum diterapkannya pembelajaran fungsi kuadrat dengan media pembelajaran Geogebra peserta didik diberikan pretest dengan tujuan untuk mengetahui kemampuan awal peserta didik. Sebagai data pembanding hasil belajar yang kaitannya dengan pengaruh penggunaan media pembelajaran Geogebra. Berikut adalah hasil pretest yang diperoleh peserta didik di kelas 9C dan 9D :

Tabel 1. Data Pretest

\begin{tabular}{ccccc}
\hline Kelas & Nilai Terendah & Nilai Tertinggi & Rata-Rata & $\begin{array}{c}\text { Standar } \\
\text { Deviasi }\end{array}$ \\
\hline $\begin{array}{c}\text { IX-C } \\
\text { (Kontrol) }\end{array}$ & 78 & 95 & 87 & 21.79 \\
$\begin{array}{c}\text { IX-D } \\
\text { (Eksperimen) }\end{array}$ & 79 & 91 & 86 & 4.67 \\
\hline
\end{tabular}

Berdasarkan Tabel 1 dapat diketahui bahwa nilai rata-rata kelas IX-C yang merupakan kelas kontrol adalah 86.5 sedangkan kelas IX-D yang merupakan kelas eksperimen adalah 87. Itu berarti nilai rata-rata kelas kontrol lebih tinggi daripada kelas eksperimen. Dari kedua kelas tersebut nilai rata-rata peserta didik sudah melampaui batas KKM (Kriteria Ketuntasan Minimum) yang telah ditetapkan di Madrasah. Namun nilai rata-rata tersebut bukan merupakan nilai yang banyak diperoleh peserta didik di kelas. Nilai pretes dari ketika kelas IX tersebut akan dianalisis dengan uji-z untuk mengetahui kemampuan awal peserta didik apakah memiliki perbedaan secara signifikan atau tidak. Uji-z tersebut pengujian statistika yang hipotesisnya didekati dengan distribusi normal. Hasil perhitungan uji-z diperoleh nilai yaitu $-1,62>-1,96$. Karena $\mathrm{z}>\mathrm{z}_{\alpha / 2}$ maka $\mathrm{H} 0$ diterima, dengan batas tolerasnsi kesalahan sebesar 5\%. Dapat diartikan bahwa pada tingkat kepercayaan 95\%, rata-rata nilai pretes peserta didik kelas IX-D yang merupakan kelas eksperimen tidak berbeda secara signifikan. Sehingga dapat ditarik sebuah kesimpulan yang dapat dikatakan kemampuan awal peserta didik kelas IX-D dan IX-C tidak berbeda secara signifikan.

2. Hasil Postest

Setelah diterapkannya pembelajaran fungsi kuadrat dengan media pembelajaran Geogebra peserta didik diberikan postest. Soal postest diberikan kepada kelas yang sama pada pretest, yaitu kelas IX-C dan IX-D. Hasil yang diperoleh dari postest bertujuan untuk mengetahui hasil belajar peserta didik pada materi fungsi kuadrat. Apakah dengan media pembelajaran Geogebra hasil belajar peserta didik mengalami peningkatan atau tidak. Alokasi waktu pengerjaan soal postest adalah sama baik di kelas IX-C ataupun IX-D yaitu selama 1 jam pelajaran atau 40 menit. Berikut adalah hasil postest yang diperoleh peserta didik di kelas IX-C dan IX-D : 
Tabel 2. Data Postest

\begin{tabular}{ccccc}
\hline Kelas & Nilai Terendah & Nilai Tertinggi & Rata-Rata & $\begin{array}{c}\text { Standar } \\
\text { Deviasi }\end{array}$ \\
\hline $\begin{array}{c}\text { IX-C } \\
\text { (Kontrol) } \\
\text { IX-D }\end{array}$ & 75 & 93 & 83 & 5,88 \\
$($ Eksperimen) & 81 & 97 & 87 & 14,53 \\
\hline
\end{tabular}

Berdasarkan Tabel 2 dapat diketahui bahwa rata-rata nilai postes kelas IX-C sebagai kelas kontrol adalah 83, sedangkan rata-rata nilai postes kelas IX-D sebagai kelas eksperimen adalah 87. Dari data nilai rata-rata postes dapat diketahui bahwa nilai rata-rata kelas IX-D lebih tinggi daripada kelas IX-C, yang berarti nilai rata-rata kelas ekperimen lebih tinggi daripada kelas kontrol. Jika dibandikan dengan hasil pretest dan postest, rata-rata nilai pretes peserta didik di kelas kontrol lebih tinggi daripada kelas eksperimen, namun sebaliknya pada hasil postes yaitu nilai rata-rata kelas ekperimen lebih tinggi daripada kelas kontrol. Dengan acuan pada hasil belajar pretest dan postest dapat disimpulkan bahwa media pembelajaran Geogebra dapat berpengaruh terhadap hasil belajar peserta didik.

Nilai postes di kelas eksperimen dan kelas kontrol dapat dianalisis mengunakan uji yang sama pada nilai pretes, yaitu uji-z. Analisis menggunakan uji-z ini juga bertujuan untuk menguji hipotesis rata-rata nilai postes. Apakah hasil belajar peserta didik menggunakan media pembelajaran Geogebra lebih baik atau tidak. Hasil perhitungan uji-z diperoleh nilai yaitu 5,27 $>1,64$. Karena $z>z_{\alpha / 2}$ maka H0 ditolak, dengan batas toleransi kesalahan sebesar 5\%. Dapat diartikan bahwa pada tingkat kepercayaan 95\%, rata-rata nilai postes peserta didik kelas IX-D yang merupakan kelas eksperimen lebih baik daripada kelas IX-C yang merupakan kelas kontrol. Sehingga dapat ditarik sebuah kesimpulan bahwa hasil belajar pesertaa didik menggunakan media pembelajaran Geogebra pada materi fungsi kuadrat lebih baik dari pada siswa yang tidak menggunakan media pembelajarn Geogebra. Dengan artian bahwa m pembelajaran dengan media Geogebra dapat memberikan pengaruh yang signifikan terhadap hasil belajar peserta didik.

Kemungkinan besar hal tersebut terjadi didukung oleh media pemebelajar Geogebra yang dapat menampilkan secara langsung grafik dari fungsi kuadrat yang diinginkan tanpa harus mengguakan cara-cara manual (menggunakan tabel). Sehingga dengan melihat secara langsung dari grafik fungsi kuadrat, peserta didik dapat menemukan sumbu simetri, niai optimum dan titik puncak dari fungsi kuadrat yang diinginkan. Peserta didik dibuat lebih mudah tanpa harus menghitung secara manual menggunakan rumus, yang kemungkinan bila dihitung dengan manual masih ada kesalahan dalam perhitungan.

Pengamatan langsung juga dilakukan oleh peneliti dalam proses pembelajaran berbantuan media Geogebra pada materi fungsi kuadrat di kelas IX-C dan kelas IX-D. Kelas IX-D sebagai kelas eksperimen lebih antusias ketika media Geogebra dinyalakan. Para peserta didik berebut untuk mencoba media pembelajaran Geogebra tersebut, sehingga mereka lebih banyak tahu mengenai materi fungsi kuadrat. Sedangkan kegiatan pembelajaran di kelas IX-C sebagai kelas kontrol, guru menjelaskan secara langsung materi fungsi kuadrat, sedangkan peserta didik hanya mencatat dan mendengarkan. Peserta didik hanya menerima penjelasan yang disampaikan oleh guru, sehingga peserta didik tidak memiliki kesempatan untuk mengali lebih banyak informasi mengenai fungsi kuadrat. 
3. Hasil Angket

Angkat berisi tentang hal-hal yang berhubungan dengan motivasi belajar peserta didik. Angket ini diberikan setelah peserta didik mengerjakan postest. Pemberian angket bertujuan untuk mengetahui motivasi belajar peserta didik pada materi fungsi kuadrat. Berikut hasil repon peserta didik mengenai motivasi belajar :

Tabel 3. Hasil Respon Peserta Didik

\begin{tabular}{|c|c|c|c|c|c|c|c|c|}
\hline No. & Kriteria & SS & $S$ & $\mathrm{R}$ & TS & STS & $\begin{array}{l}\text { Persentase }(\%) \\
\text { respon positif }\end{array}$ & Ket \\
\hline 1 & $\begin{array}{l}\text { Apakah tampilan media } \\
\text { pembelajaran Geogebra } \\
\text { menarik? }\end{array}$ & 14 & 11 & 3 & 0 & 0 & $89.28 \%$ & Positif \\
\hline 2 & $\begin{array}{l}\text { Apakah media } \\
\text { pembelajaran Geogebra } \\
\text { mudah digunakan? }\end{array}$ & 20 & 8 & 0 & 0 & 0 & $100 \%$ & Positif \\
\hline 3 & $\begin{array}{l}\text { Apakah teks/tulisan pada } \\
\text { media pembelajaran } \\
\text { Geogebra dapat dibaca } \\
\text { dengan jelas? }\end{array}$ & 18 & 8 & 2 & 0 & 0 & $92.85 \%$ & Positif \\
\hline 4 & $\begin{array}{l}\text { Apakah media } \\
\text { pembelajaran Geogebra } \\
\text { membuat Anda lebih } \\
\text { bersemangat dalam } \\
\text { belajar? }\end{array}$ & 17 & 6 & 4 & 1 & 0 & $82.14 \%$ & Positif \\
\hline 5 & $\begin{array}{l}\text { Apakah belajar } \\
\text { menggunakan media } \\
\text { pembelajaran Geogebra ini } \\
\text { menyenangkan/tidak } \\
\text { membosankan? }\end{array}$ & 13 & 11 & 4 & 0 & 0 & $85.71 \%$ & Positif \\
\hline 6 & $\begin{array}{l}\text { Apakah media } \\
\text { pembelajaran Geogebra } \\
\text { memudahkan Anda untuk } \\
\text { menerapkan rumus-rumus } \\
\text { pada materi fungsi } \\
\text { kuadrat? }\end{array}$ & 19 & 6 & 3 & 0 & 0 & $89.28 \%$ & Positif \\
\hline 7 & $\begin{array}{l}\text { Apakah media } \\
\text { pembelajaran Geogebra } \\
\text { membantu Anda untuk } \\
\text { meyelesaikan soal-soal } \\
\text { yang berkaitan dengan } \\
\text { fungsi kuadrat? }\end{array}$ & 24 & 3 & 1 & 0 & 0 & $96.43 \%$ & Positif \\
\hline
\end{tabular}




\begin{tabular}{|c|c|c|c|c|c|c|c|c|}
\hline No. & Kriteria & SS & $S$ & $\mathrm{R}$ & TS & STS & $\begin{array}{l}\text { Persentase }(\%) \\
\text { respon positif }\end{array}$ & Ket \\
\hline 8 & $\begin{array}{l}\text { Apakah media } \\
\text { pembelajaran Geogebra } \\
\text { memberikan dorongan } \\
\text { untuk mempelajari materi } \\
\text { fungsi kuadrat lebih } \\
\text { dalam? }\end{array}$ & 14 & 11 & 2 & 1 & 0 & $89.29 \%$ & Positif \\
\hline 9 & $\begin{array}{l}\text { Apakah penggunaan } \\
\text { media pembelajaran } \\
\text { Geogebra dapat membuat } \\
\text { Anda lebih mudah } \\
\text { mengingat dan memahami } \\
\text { materi fungsi kuadrat? }\end{array}$ & 15 & 9 & 2 & 1 & 0 & $85.71 \%$ & Positif \\
\hline 10 & $\begin{array}{l}\text { Apakah media } \\
\text { pembelajaran seperti ini } \\
\text { sebaiknya diterapkan } \\
\text { dalam materi Matematika } \\
\text { lainnya? }\end{array}$ & 12 & 11 & 4 & 1 & 0 & $82.14 \%$ & Positif \\
\hline \multicolumn{2}{|c|}{ Rata-rata persentase respon positif } & & & & & & $89.28 \%$ & Positif \\
\hline
\end{tabular}

Berdasarkan respon peserta didik diatas, menunjukkan bahwa pembelajaran berbantuan Geogebra dalam materi fungsi kuadrat ditinjau dari respon peserta didik memiliki rata-rata $89.28 \%$ yang diikuti oleh 28 peserta didik pada kelas IX-D yang erupakan kelas eksperimen. Dari keseluruhan aspek yang ditanyakan, respon peserta didik memiliki respon yang tinggi. Dengan tingginya persentase peserta didik yang memberikan respon positif berarti bahwa media pembelajaran Geogebra berpengaruh terhadap motivasi belajar peserta didik. Hal tersebut disebabkan oleh media pembelajaran Geogebra belum pernah digunakan oleh peserta didik, sehingga peserta didik penasaran dan tertarik untuk mencoba mempelajari materi fungsi kuadrat dengan bantuan media pembelajaran Geogebra.

Pengamatan secara langsung juga dilakukan oleh peneliti, sebagai data penunjang hasil angket. Peneliti melihat secara langsung peserta didik di kelas IX-D yang merupakan kelas eksperimen lebih aktif daripada peserta didik di kelas IX-C yang merupakan kelas kontrol. Selama proses pembelajaran berlangsung banyak peserta didik bertanya mengenai media pembelajaran Geogebra, karena penasaran. Sedangkan kelas kontrol peserta didik hanya diberikan kesempatan untuk mendengarkan penjelasan guru, sehingga peserta didik kurang tertarik untuk mempelajari fungsi kuadrat.

\section{SIMPULAN}

Berdasarkan hasil penelitian pengaruh media pembelajaran Geogebra pada materi fungsi kuadrat terhadap motivasi dan hasil belajar peserta didik di MTs Negeri Gresik dapat ditarik kesimpulan sebagai berikut :

1. Media pembelajaran Geogebra pada materi fungsi kuadrat berpengaruh terhadap motivasi belajar peserta didik.

2. Hasil belajar peserta didik menggunakan media pembelajaran Geogebra pada materi fungsi kuadrat lebih baik daripada peserta didik yang tidak menggunakan Geogebra. 
Berdasarkan kesimpulan diatas, peneliti memberikan saran sebagai berikut :

1. Bagi sekolah

Pihak sekolah memberikan sarana dan prasarana yang lebih untuk menunjang kegiatan pembelajaran guna meningkatkan motivasi belajran peserta didik. Demi terwujudnya prestasi akademik yang lebih baik dan sekolah dapat memperbaiki mutu pendidikan yang lebih maju.

2. Bagi guru

Semua guru diharapkan mampu memberikan inovasi-inovasi pembelajaran yang lebih baik dari aspek media maupun model pembelajaran. Dengan inovasi inovasi baru mampu menciptakan peserta didik yang aktif dan mampu bersaing di industri luar.

3. Bagi peneliti

Penelitian yang dilakukan memiliki banyak kekurangan, sehingga diharapkan peneliti lain dapat termotivasi untuk mengembangkan penelitian yang lebih baik.

\section{DAFTAR PUSTAKA}

Ali Syahbana. (2016). Belajar Menguasai GeoGebra (Program Aplikasi Pembelajaran Matematika). NoerFikri Offset: Palembang.

Aminah Ekawati. (2016). Penggunaan Software Geogebra Dan Microsoft Mathematic Dalam Pembelaran Matematika. Math Didactic. Jurnal Pendidikan Matematika 2:(3), 148.

Gede Alit Narohita. (2014). Pemanfaatan Geogebra Untuk Meningkatkan Pemahaman Karakteristik Grafik Fungsi Kuadrat Pada Siswa Kelas X MIA7 SMA Negeri 1 Singaraja. Indonesian Digital Journal of Mathematics and Education. 18:(2), 3-4.

Putri Fitriasari. Pemanfaatan Software Geogebra Dalam Pembelajaran Matematika. Universitas PGRI Palembang Email : putrifitriasari20@gmail.com.

Isman M. Nur. (2016). Pemanfaatan Program Geogebra Dalam Pembelajaran Matematika. Delta-Pi. Jurnal Matematika dan Pendidikan Matematika 5:(1), 10.

Ita Nurmuiza, dkk. (2015). Pengaruh Motivasi Belajar Terhadap Hasil Belajar Matematika Siswa SMAN. Jurnal Pendidikan Matematika. 6: (2), 57. 